\title{
Financial aspects of Public-Private Partnership
}

\author{
UDK: 351.712(497.4) \\ Livijo Sajko \\ Faculty of Philosophy, University of Rijeka \\ livijo.sajko@ri.t-com.hr
}

\begin{abstract}
The growth of public requests is evident in the case of Croatia, but also present in every European country, with the government's lack of ability to secure sufficient financial income. The look for additional sources of financing, in order to build public infrastructure, is directed therefore more and more to the private financing capital and to public-private partnerships. Together with such trends, one of the main questions that arise is, whether the employment of private capital in PPP-projects is valid from the economy point of view? If the overall project costs in the PPP-model are lower than the one in the traditional public sector model, calculated with the method of a Public Sector Comparator, the decision can be made to employ private capital in PPP-projects, which is valid from the economy point of view.
\end{abstract}

Key words: public-private partnership, public requests, private capital, Public Sector Comparator

\section{Introduction}

In the projects realised through the public-private partnership (PPP) model, the public sector transfers the performance of public tasks to the private sector. By transferring the public tasks to a private partner, a mobilization effect of the intellectual, human and financial capital of the private sector is attained, which makes the public service delivery more efficient. For this purpose a general PPP-model has to be developed, to fit in different types of PPP and to mobilize private capital, needed for the overcome of capital shortages in public budgets for the construction of public infrastructure.

The growth of public requests is evident. On the other side a lack of ability to secure sufficient financial incomes in the public budgets is present, with the need for additional sources of financing. Such sources can be secured trough private capital in financing PPP-projects. That may be the reason for a fast developing European PPP-market. But the question that rises more and more 
Livijo Sajko

Financial aspects of Public-Private Partnership

often in such a situation is, whether the employment of private capital in PPPprojects is valid from the economy point of view?

To give an answer to this question, the functions and importance of private investors has to be taken in consideration. A Public Sector Comparator (PSC) has to be developed, in order to decide about financing the PPP-project by private or public capital possible. Several private capital sources are available for this purpose.

In the case analysis of the City of Monheim (Germany) it becomes evident, how a PPP-project can be financed by private capital, even if the financial costs are higher than in a traditional model of building public infrastructure.

\section{General theoretical characteristics of Public- Private Partnership}

\subsection{The general model of PPP and of financing the PPP-projects}

The basic characteristic of a PPP is the cooperation and collaboration of public and private partners in public services delivery, in a more effective way. In order to reach such a goal, there is no need for competition between the public and private sector, but only for cooperation and partnership (Smith, 1999, p. 131-137).

The certainty of building up partnership relations has its origins in the principal-agent theory and property-rights theory (Otten, 2005, p. 7-8). By the implementation of these theories into PPP-projects, it is figured out, that the public sector's interest is to reach a common welfare, while the private partner aims for a profit, which may lead to the conflict of interest. It is therefore the main objective to make the private partner reach his profit, but in a way that will ensure common welfare. Further on, both partners will feel motivated to make the PPP-project successful, if they have ownership rights over the PPPproject. As public tasks are public goods, these ownership rights can be transferred to the private partner only over a limited time and only with a strong control of the public sector over the performance of the private partner. This calls for a careful and detailed preparation of the PPP-project and the contracts that are related to the project. 
Picture 1: The general model of PPP-participants and the PPP-project financing

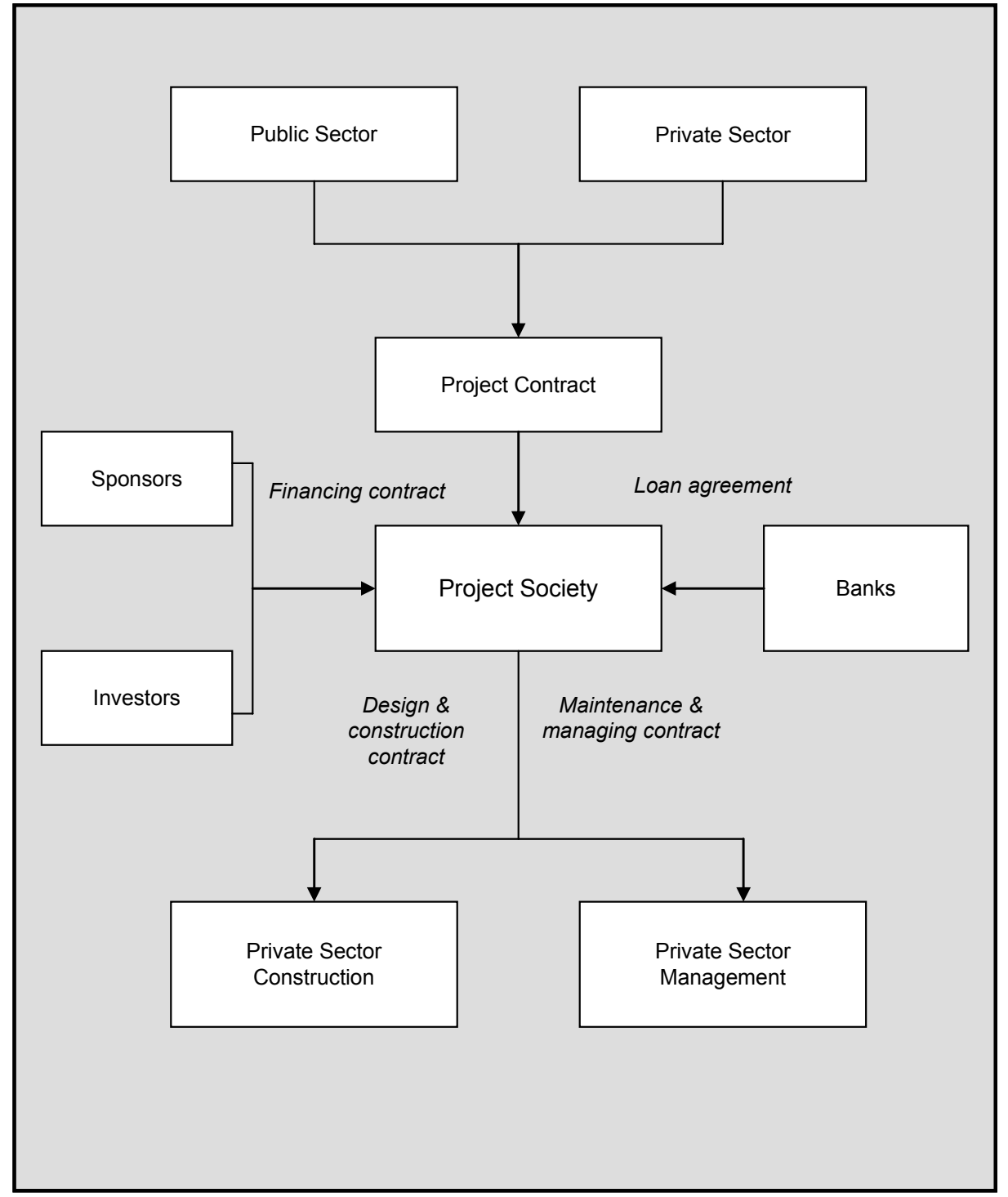

Source: PPP - Initiative NRW (2004): Finanzierungsleitfaden, Finanzministerium NRW, p. 17

Therefore, the establishment of a joint (public/private) project society is recommended, as a general model of PPP. Ownership rights and obligations of the partners in the joint project society are regulated by a special project contract. The design and the building of the public project are regulated by designing and construction contracts, as well as the financing of the public project is 


\section{Livijo Sajko}

\section{Financial aspects of Public-Private Partnership}

regulated by loan agreements or financing contracts. In the end, the operating of the public project has to be regulated by maintenance and managing contracts. All these contracts are bundled in one main PPP-project contract.

The main criterion in the transfer of public tasks to the private sector is the "value for money" principle. As the private sector uses public resources in work and as it is receiving compensation for this work from the public sector or/and from the final users, it has to produce the public product or service in a way, that ensures some main values or outcomes (efficiency, effectiveness, savings, quality). This is reached by optimal allocation of the business risks between the public and private partners (PPP-Initiative NRW, 2003, p. 13).

If the public sector transfers to the private partner only one part of the public tasks (build and operate), then we can talk about a build-operate-transfer or BOT-model. The ownership over the public project is also transferred to the private partner, but must be given back to the public sector after the conclusion of the contract. The public sector will detain $51 \%$ of the ownership over the joint project society, with the possibility of controlling the private partner. The risks are taken over by that partner, who has more efficiency in the risk management of a specific business risk.

If the public sector transfers all the public tasks (design, build, finance, operate) to the private sector, we can talk about a design-build-finance-operate or DBFO-model. The ownership over the public project and the ownership over the joint project society is transferred to the private partner, but has also to be given back to the public sector after the conclusion of the PPP-contract. By bundling the public tasks in one transfer to the private sector, a better motivation of the private partner is created in the performance of public service delivery. The public sector will keep supervision and controlling rights over the project society and the private partner (PPP-Initiative NRW, 2003, p. 16-17).

\subsection{Public-private partnership - definition and classification}

PPP can be therefore defined as a joint cooperation activity of the public and private sector and as complex and long-term contract collaborations in public service delivery.

The main characteristics of PPP's are:

- A long-term (20 to 25 years) collaboration between the public and private partner; 
- A transfer of ownership to the private partner but only over a limited period;

- An optimal allocation of business risks between the public and private sector and

- An overall responsibility of the private partner in public service delivery, controlled by the public sector.

The PPP is positioned between the traditional model of public service delivery and privatisation and can appear in several forms (Gasteyer, 2003, p. 11-14):

- Informal cooperation's - exchange of information between the partners;

- Public law cooperation's - concessions;

- Civil law cooperation's - long-term rent, leasing, supply and rendering contracts;

- Partial privatisation - a minority transfer of constitution rights to a private partner;

- Social law cooperation's - public-private joint project societies.

\section{Public requests and possibilities of how to finance them}

\subsection{Trends related to the growth of public requests in the case of Croatia}

The growth of public requests is present in every European country, in all public administration sectors, especially in the transportation of goods and people.

In chart 1 the development of the transportation of goods and passengers, in the case of the Republic of Croatia, in the period from 1996 to 2005, is presented. The transport of passengers by railroads has grown by $36,9 \%$, while the transport of goods has increased by $29,6 \%$. The transport of passengers in maritime ports in Croatia has increased by $121 \%$, while the transport of goods grew by $87,5 \%$. The travelers' traffic in the airports has grown by $144 \%$, while the transport of goods by air grew by $16,3 \%$, with the 
Livijo Sajko

Financial aspects of Public-Private Partnership

fact that $86 \%$ of the overall transport of travelers and goods is realised by the Zagreb Airport (Zagreb Airport, Statistics).

\section{Chart 1: Transports of goods and travelers in the Republic of Croatia}

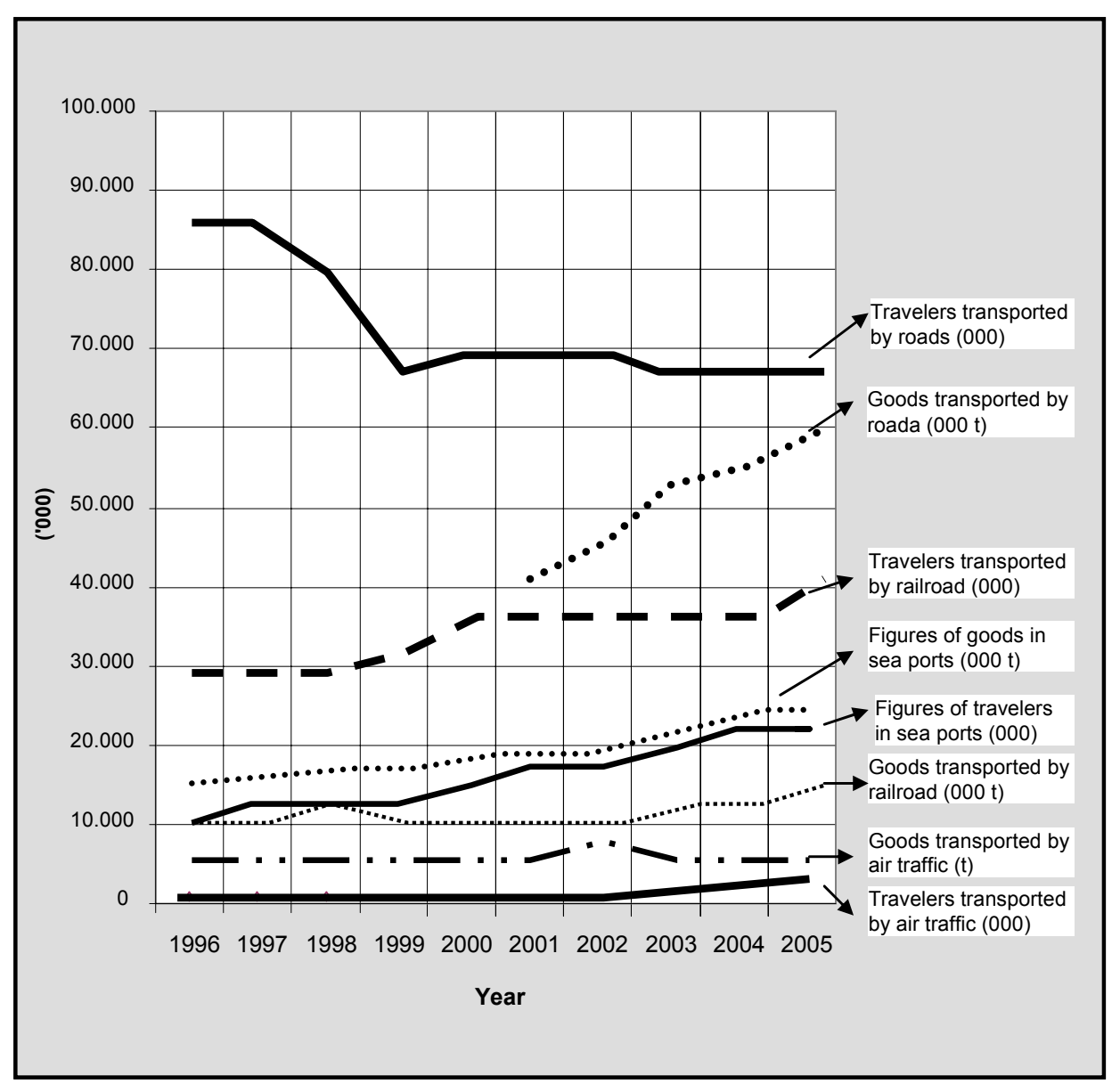

Source: Republika Hrvatska - Državni Zavod za Statistiku, Statistički ljetopis 2006

The most important changes are present in the road traffic. Unfortunately, statistic data for this segment were not registered prior to 2001 . While in the period between 1996 and 2005 the number of travelers transported by roads decreased by $25 \%$, the percentage of goods transported in the same way grew by $44 \%$, in the period from 2001 to 2005. In the period considered, the number of registered vehicles increased by $78 \%$ (from 1.008 .878 vehicles to $1.790 .971)$, with the automobiles share grown by $66 \%$, which can explain the 
decrease of public road transport of passengers (Republika Hrvatska - Državni Zavod za Statistiku, Statistički ljetopis 2006).

Similar growth tendencies exist also in other public segments, such as electrical energy production, maritime and shore transit of passengers, oil pipelines, water supply, drainage networks and similar.

\subsection{Public requests financing trends in the case of Croatia and the City of Rijeka}

To evaluate the fiscal conditions in the public budgets and to identify the financial assets that are available to be invested, in order to satisfy the previously determined requests, a public financial analysis framework has been used (Sikirić, 2004, p. 307-309).

The chart 2 clearly shows that the net operative results of the City of Rijeka, if we exclude the year 2002, are negative. A negative net operative result suggests, that there remained no financial capacity for further indebtedness.

Further on, the capital outlays are in principle higher than the capital revenues. If movements of capital revenues and capital outlays are added to the operative result, requests for capital assets are obtained. These requests can be fixed in the amount of 15,2 million of Kuna in 2005 to 58,3 million Kuna in 2004, with the tendency of a strong growth in the period between 2002 and 2004.

The chart 3 demonstrates how the City of Rijeka meets its capital assets requests. In the period of 2002 to 2004 this problem was resolved by new indebtedness. In the period that follows, the administration resolved the capital assets request by issuing of securities. This trend is demonstrated through the growth of the net financial transactions, with loan income and disbursement items eliminated.

Analysing the local administrations in the Republic of Croatia as a whole and applying the same financial analysis method, the following results are gained: in the period from 2003 to 2006, capital requests grew from 385 million Kuna to 1,4 billion Kuna. The main instrument of meeting these requests in the stated period was the stipulation of loan agreements. The local administrations were averagely indebted by 525 million Kuna a year. The net financial transactions (securities) in the year 2004 resulted in 108 million Kuna of revenues. In 2006, the same figures amounted to 222 million Kuna (Ministarstvo financija Republike Hrvatske, Državni Proračun). 
Livijo Sajko

Financial aspects of Public-Private Partnership

Chart 2: Capital assets requests - City of Rijeka

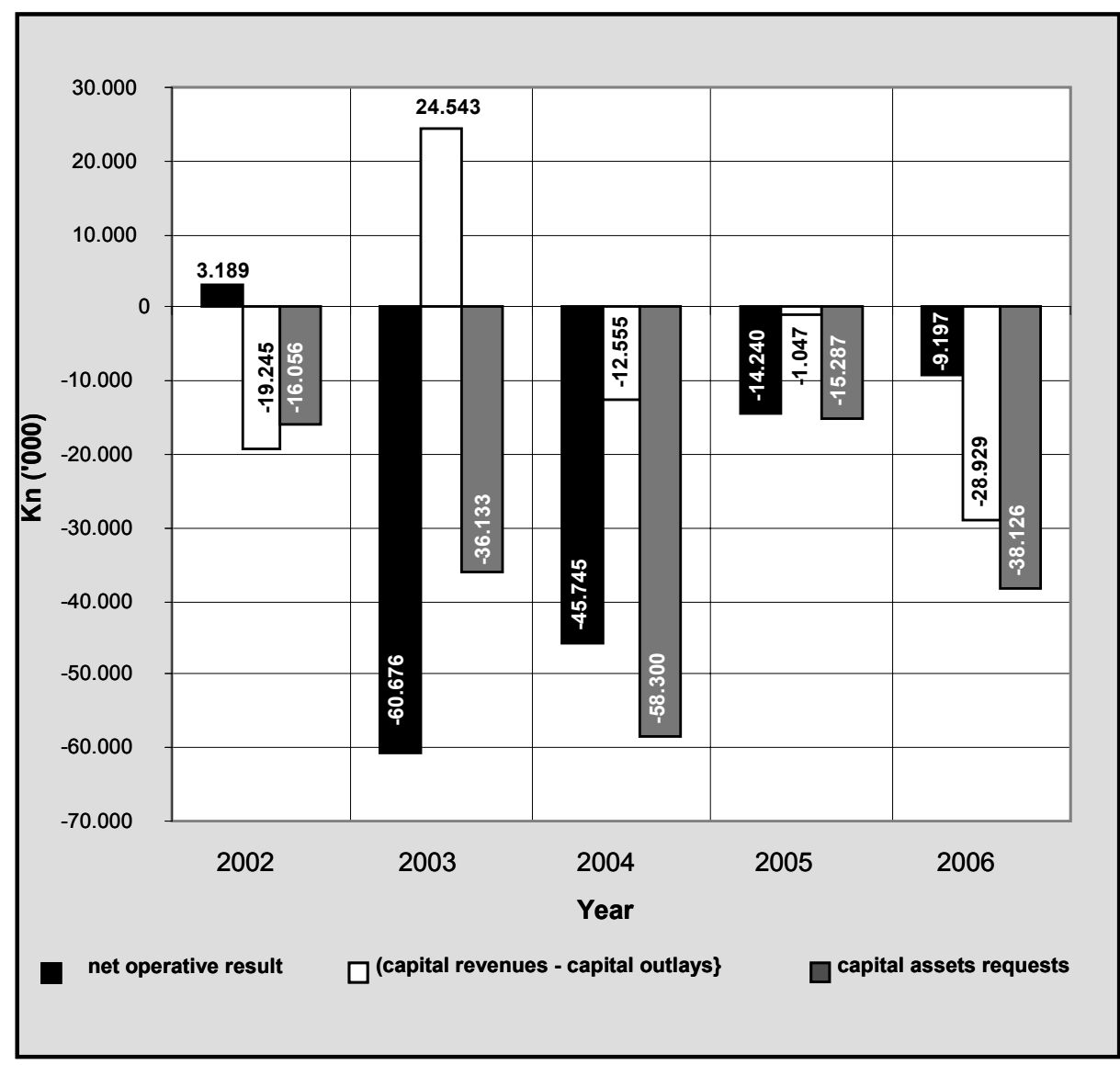

Source: Grad Rijeka, Proračun

In the National Budget of Croatia, in the same period, regular outlays are constantly higher than the regular incomes, what causes negative net operative results (3,7 billion to 8,8 billion Kuna). The National Budget has no financial capacity for further debts. The capital outlays are far above the capital income, which creates a growth of capital assets requests from 5,7 billion Kuna in 2002 to 10,3 billion Kuna in 2004. During the next two years, this trend stagnated to 8,7 billion Kuna in 2005 and 9,7 billion Kuna in 2006. The State administration averagely debits by 3 billion Kuna and the issuing of securities results in an income of 5,5 billion Kuna a year (Ministarstvo financija Republike Hrvatske, Državni Proračun). 


\section{Chart 3: Indebtness and net financial transactions - City of Rijeka}

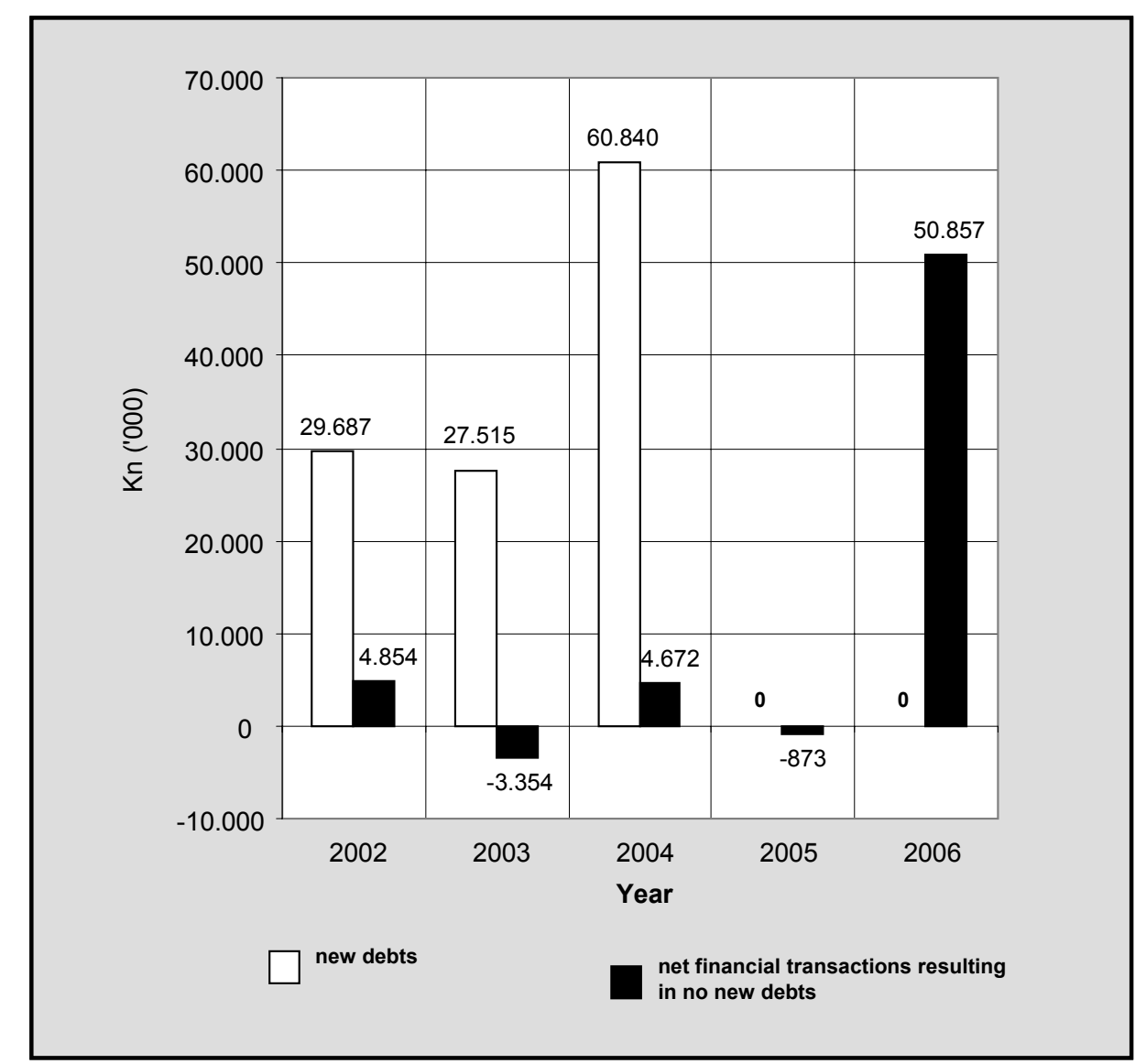

Source: Grad Rijeka, Proračun

A similar development of fiscal conditions in the public budgets of other European countries can be identified, as well as the financial assets that are available to be invested, in order to satisfy the requests.

\subsection{Public-private partnership development}

In such circumstances, with the state's lack of ability to secure sufficient financial incomes, it is not reasonable to stop the public infrastructure in its growth and development. The look for additional sources of financing, in order to build public infrastructure, is directed therefore to the private capital and to 


\section{Livijo Sajko}

\section{Financial aspects of Public-Private Partnership}

PPP's. The trends of the PPP-market can be taken as an indicator for such a development.

According to available data, it is possible to take an insight on the PPPmarket development for France and Germany, as data for Croatia or other countries are not available.

\section{Chart 4: French PPP market}

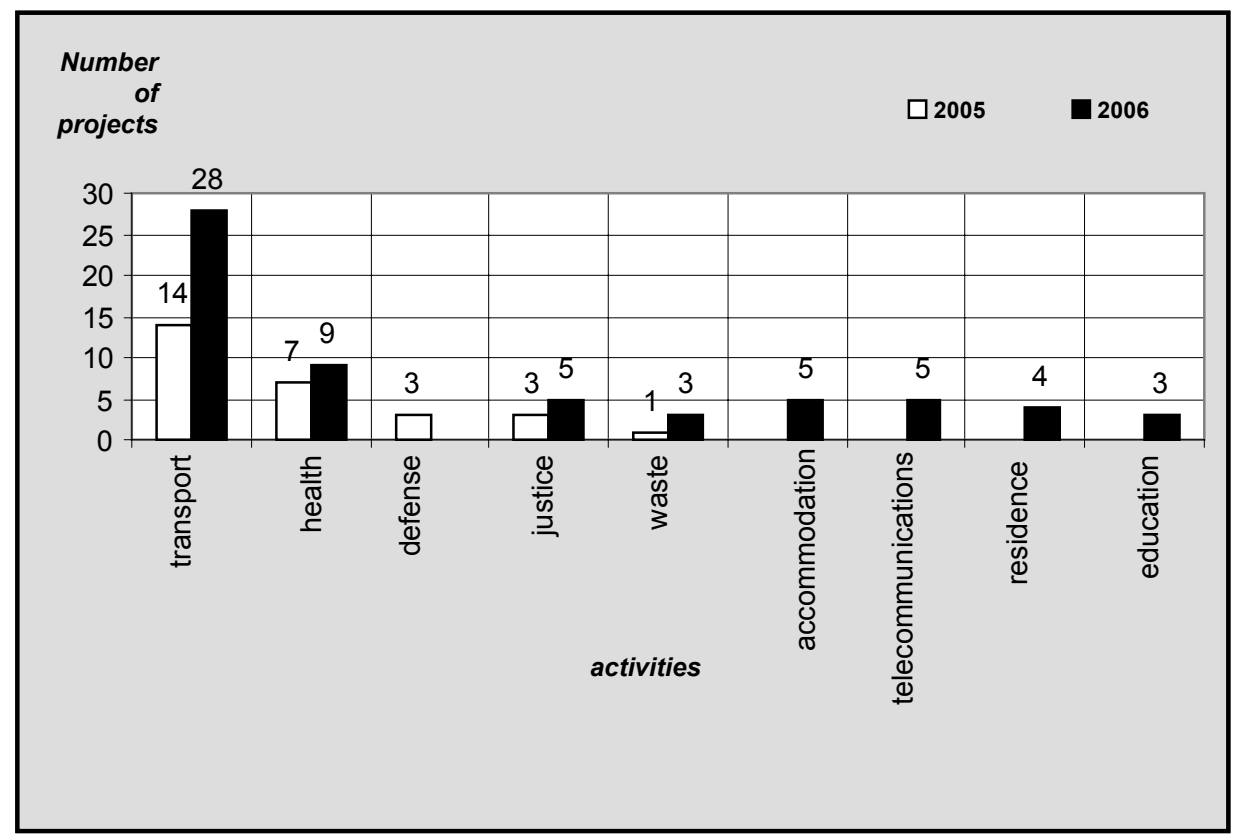

Source: Public Private Finance, Europe Country Studies

During the year 2005 a total of 28 PPP-projects have taken place in France, with the number increased during the 2006 to 62 projects. Chart 4 demonstrates that in France in 2006 projects in the segment of transport of travelers and goods reduplicated. The projects entering the segment of health, justice and waste disposal are slightly growing. The PPP-models have also found an application in other fields of the public sector, as social welfare accommodations, telecommunications, residential buildings and education.

In Germany, during 2005, a total of 40 projects has been realised, which number increased in 2006 to a total of 106 projects. As shown in chart 5, the German PPP-market is growing in the field of transportation, health, social accommodation, telecommunication, residential units, and education. 


\section{Chart 5: German PPP market}

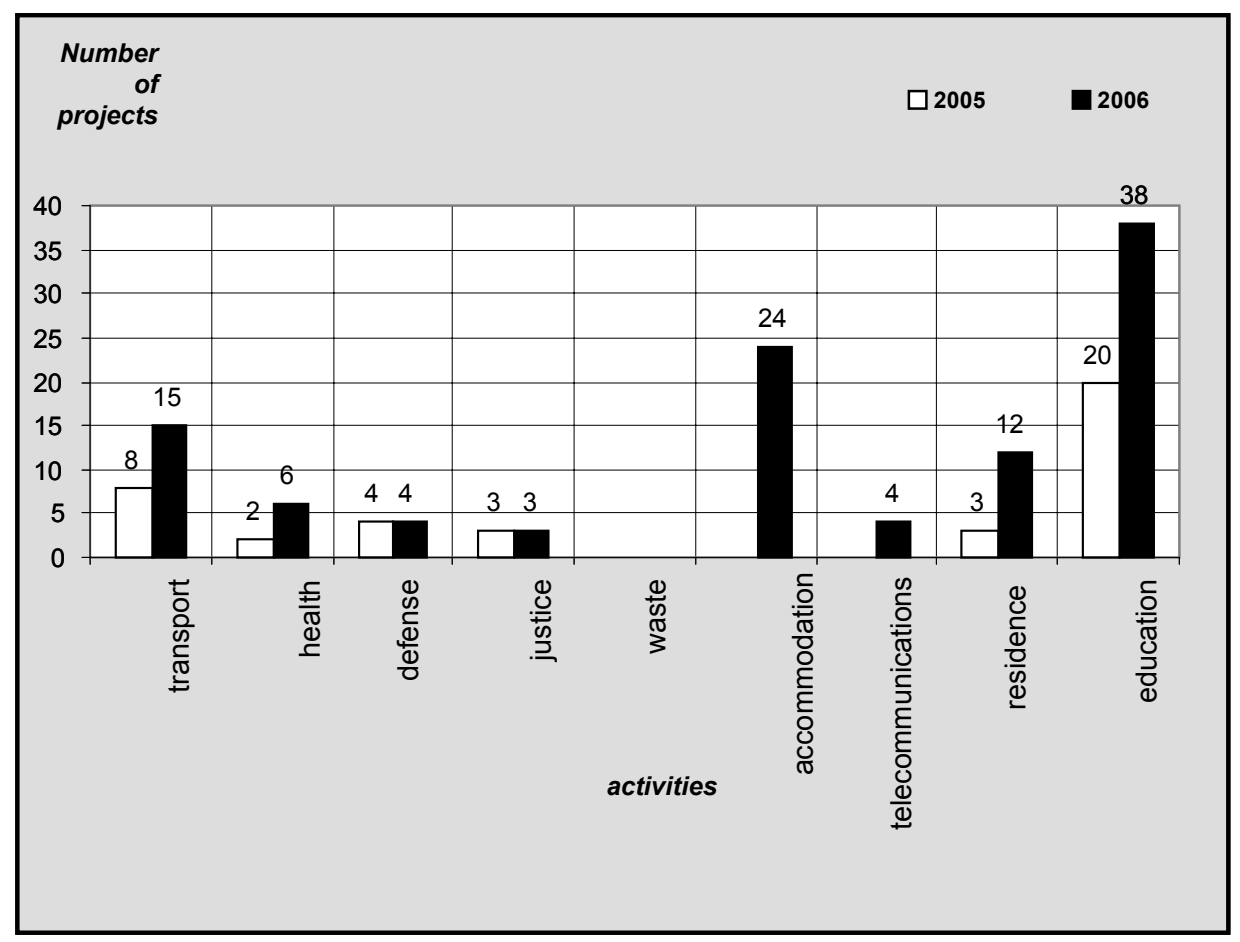

Source: Public Private Finance, Europe Country Studies

\section{Financing of Public-private Partnership Projects}

\subsection{Functions and importance of a private investor}

When public infrastructure is built by a PPP-model, what is more and more the case as we could see, one of the main questions that arise is, whether the employment of private capital in PPP-projects is valid from the economy point of view?

Chart 6 shows that the interest rates at the money market in Croatia have a positive movement. From 2000 and on, the interest rates have been fixed at a rate below $5 \%$. The movement of the discount rate of the central bank is also positive, what makes financing through the issuance of securities also favourable, since the discount rate is also below $5 \%$. Such trends are similar to other European countries. 
Livijo Sajko

Financial aspects of Public-Private Partnership

\section{Chart 6: Interesand and discount rates in the Republic of Croatia}

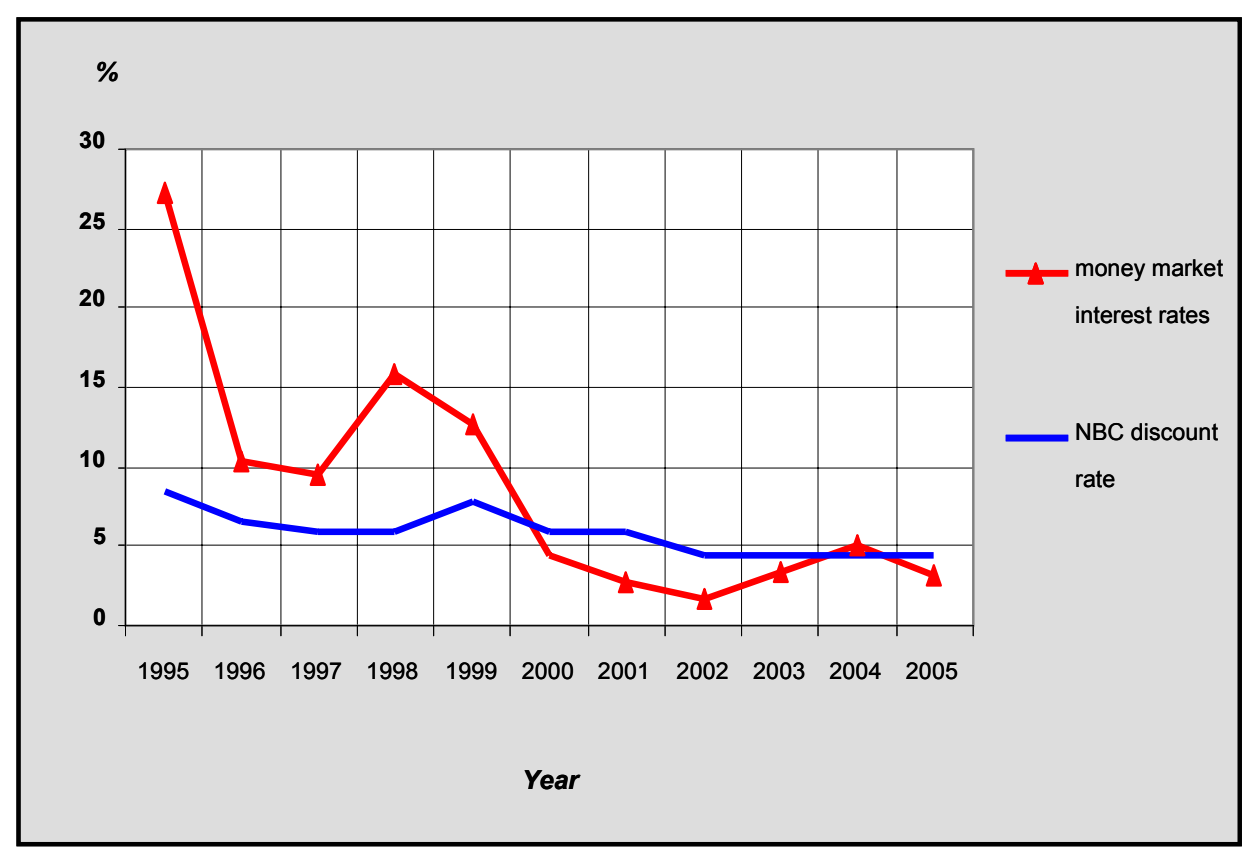

Source: Hrvatska Narodna Banka, Statistika

This points to a favourable condition in financing the public infrastructure projects directly by the public sector. The engagement of private capital will regularly require higher interest rates then the ones described above.

But then the private partner takes over no refinancing liability, which significantly lowers his readiness to be as efficient as possible. The motivation of the private sector to optimise costs within the entire cycle of the project is brought to almost zero. His motivation to rationalize total project costs is significantly diminished. Certain functions which are brought by the private partner, such as promptness of capital accessibility, evaluation of the project, supervision, optimisation of overall costs and dividing of risks and efficiency, are lost if the private partner is not included in the project.

\subsection{Financing costs and conditions of financing}

The financing costs cannot be considered isolately, but through the total project costs that came up in the overall duration of the project. It is necessary to elaborate comparable feasibility prognosis, called also Public Sector Comparator - PSC (Jacob, 2003, p. 31). In such a way higher costs of private fi- 
nancers, contained within the agenda item "financial costs", may be compensated through savings, realised by more efficiency of the private partner, in other project items, such as "design", "build" or "operate".

Let us assume that the PSC will have the item "finance" entered at the side of the PPP-model higher then the one entered at the side of the traditional model. An isolated consideration of financial costs in such a way will lead us to a decision towards financing the infrastructure project by the public sector. If we then assume that the remaining items (design, build, operate and others) in the PSC are less in the PPP-model than in the traditional model, an isolated consideration of this costs can create a decision of transferring this public tasks to the private partner - the public sector will finance and the private partner will design, build and operate.

If we make the public tasks transfer decision in such a way and not by comparing the overall project costs, we will loose the mentioned advantages of the private investor, which can eliminate the savings or lessen amounts in the project items design, build and operate.

\section{Picture 2: Comparable calculation of PPP project feasibility - PSC}

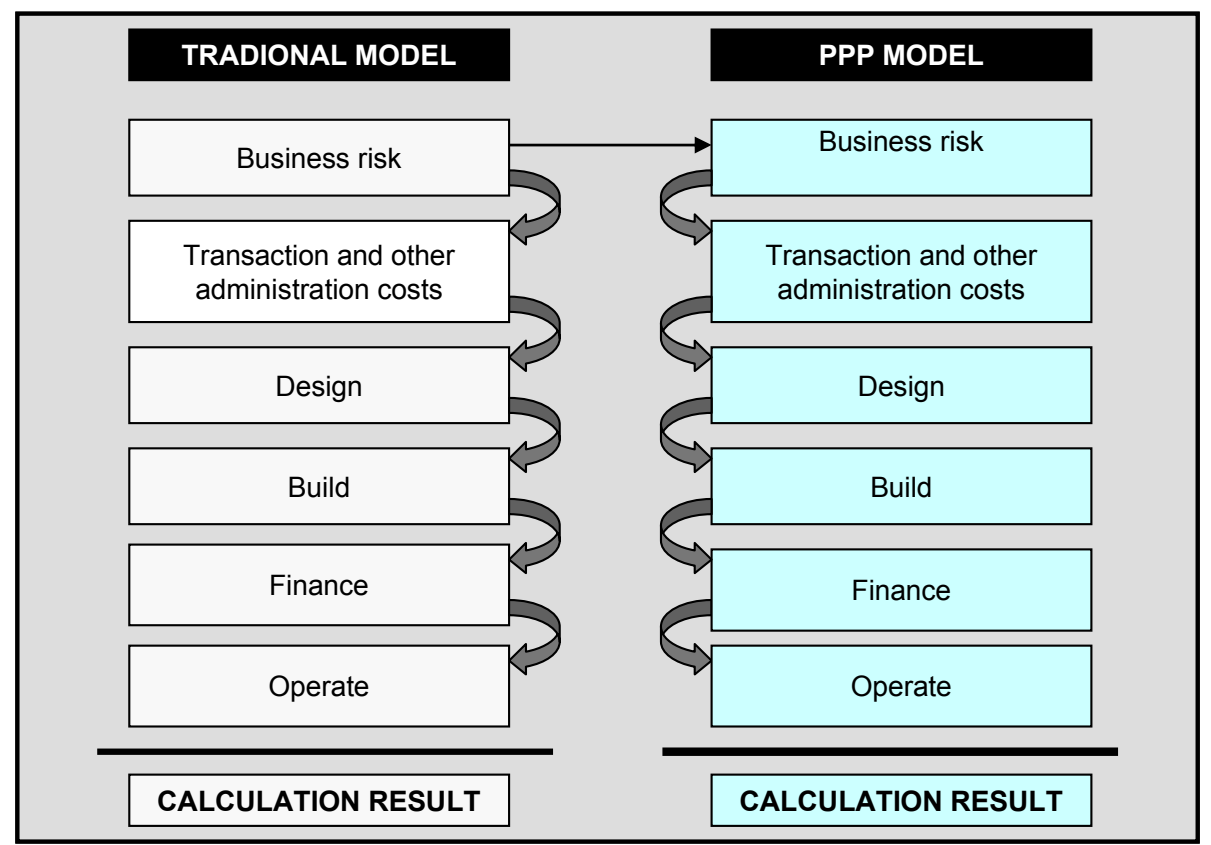

Source: PPP-Initiative NRW (2003): Wirtschaftlichkeitsvergleich, Finanzministerium NRW 


\section{Livijo Sajko}

\section{Financial aspects of Public-Private Partnership}

Therefore the overall project costs (calculation results) have to be considered. If the calculation result in the traditional model is lower than in the PPPmodel, the project will be realised directly through the public sector. If the calculation results show that the traditional model is more expensive than the PPP-model, the project can be realised through PPP. The transfer of bundled public tasks is therefore recommended.

\subsection{Capital sources}

As it has been discussed, the public sector can finance an infrastructure project directly from the public budgeted expenditures or by the capital acquired by issuing securities. Should the public sector not dispose with such options, which is very often the case, private capital can be invested through PPP. In both cases we talk about own capital investments (Jurčić, 2001, p. 141).

But the private partner, who is engaged for the design, build, finance and operate of the public project (a construction company for example) is mostly also not disposing with his own capital. In this case the established PPPproject society has several capital sources for financing a PPP-project (see picture 1): banks, sponsors and investors.

If the partners make a loan agreement with commercial banks then they have the obligation to pay back the credit with interests. Sponsors are active investors, investing their own capital directly into the ownership structure of the PPP-project society, rendering the capital available in every phase of the project development. The payback of the sponsor's investment can be secured by commercial businesses performed trough the PPP-project society. Investors or passive investors are investing also own capital, but without managing the business or property. The payback of such an investment is long-term orientated, trough the profit of the PPP-project society.

It is not often possible to develop commercial businesses and to ensure high and stabile profits or regular incomes from users fees by the PPP-project society. This is mostly the case in non-commercial public sectors, like public education or public health. For this reason, the most usual form of financing the PPP-project is a loan or credit agreement with a commercial bank (Jurčić, 2001, p.140-144; Merna, 2002, p. 130-134; Walker, 1999, p. 83-97).

A special capital source is the "Mezzanine capital". It is typically used to finance the expansion of existing companies. Mezzanine financing is basically 
debt capital that gives the lender the rights to convert to an ownership or equity interest in the company, if the loan is not paid back in time and in full. Since mezzanine financing is usually provided to the borrower very quickly, this type of financing is aggressively priced, with the lender seeking a return with an interest rate of 20-30\%. (PPP-Initiative NRW, 2004, p. 29).

\section{Case analysis - City of Monheim, Germany}

In Croatia some new PPP-projects have been launched. As these projects are the beginning of their development, data collection is so far not possible. Therefore a case analysis of a PPP-project of the City of Monheim, in the county of Nordrhein-Westfalen in Germany, is presented (http://www. monheim. De/stadtprofil/schulen/ppp/).

In 2001 the City of Monheim was faced with a high demand of school sanitation, because 12 of 13 city school complexes (40 school objects) were build before 1980, in which time no maintain investments for the school buildings where made. At the same time a lack of capital expenditures for this purpose was figured out, in an average amount of 7,5 mil euro a year, with the goal to finish the sanitation of the school buildings up to 2006. In such circumstances a decision was made, to realise the school sanitation by a PPP.

After the employment of PPP-advisers in 2002, a PPP-model for school sanitation was developed, with the following characteristics:

- As only school building sanitation is considered, there is no need for a new design of the school buildings.

- The public tasks that will be transferred to the private partner are therefore building, financing and operating of the school objects (BFO-model of PPP).

- The establishment of a project society, whereby the public and private partners will have equal shares in ownership, will realise the BFO-model, but the director of the project society must be from the public sector.

- The duration of the partnership is fixed by 25 years.

- The private partner will make loan agreements with a commercial bank for financing the PPP-project.

- All the 12 schools will be bundled into one major PPP-project.

- The sanitation part of the PPP-project has to be done by 2006 . 


\section{Livijo Sajko}

\section{Financial aspects of Public-Private Partnership}

After the presentation of the proposed PPP-model to public officials in 2002, a new decision was made: during 2003 the PPP-school project has to be tested on his economics by a Public Sector Comparator. The research and the results of this test (Jacob, 2003, p. 21) are shown as follows:

- The sanitation of 12 schools with 40 objects will cost the public sector 28 mil euro in building costs, 9,8 mil euro in financing costs, 16 mil euro in operating costs and 46,2 mil euro in administration cost, including the salary of public employees, if the project is realised in a traditional way.

- The realization of the school project with a PPP-model will cost the project society 21 mil euro in building costs, 10,3 mil euro in financing costs, 14,4 mil euro in operating costs and 41,8 mil euro in administration costs, including the salary of employees of the project society.

- The overall cost of the traditional model for 25 years is 100 mil euro, whereby the overall cost of the PPP-model for the same period is 87,5 mil euro, which makes a saving of 12,4 mil euro or $12,4 \%$.

- Fragmented the savings are: $25 \%$ in building, $10 \%$ in operating and $11 \%$ in administration costs, only the financing costs are higher for $5 \%$ in the PPP-model.

After the PSC the decision was made to launch in 2003 an international European wide public tender for PPP in the City of Monheim, with the transfer of build, finance and operate to the private partner. The German construction company "Kircher/Serco GmbH" has in this tender shown the best solutions for realising the PPP-project. Up to 2006 the sanitation of the school objects has been done, while the operating business of the schools goes on until 2029.

\section{Conclusion}

The growth of public requests is evident in the case of Croatia, but also present in every European country, in all public administration sectors.

On the other side, the capital expenditures are higher than the capital revenues in the public budgets and the request for capital assets has a tendency of strong growth, what is clearly shown in the case of the City of Rijeka. That causes a problem in financing of public infrastructures. This problem is 
resolved by new indebtedness, even when there is no financial capacity for further indebtedness. Therefore, new methods of financing public infrastructure are used, like the issuing of securities. The same public budget statuses are recognized on the level of the whole local administration and in the National Budget of Croatia.

In such circumstances, the look for additional sources of financing, in order to build public infrastructure, is directed more and more to the private capital and to PPP. This can be proved by the development of the French and German PPP-market, with a growth of PPP-projects over $200 \%$ a year (2005/2006), mostly in the public sectors of transportation, public health care and public education.

As the implementation of PPP-projects is growing more and more, one of the main questions that arise more and more often is, whether the employment of private capital in PPP-projects is valid from the economy point of view?

The financial trends presented in the case of Croatia, but also similar to other European countries, are pointing to favourable interest and discount rates in financing public infrastructure projects directly by the public sector. The engagement of private capital regularly requires higher interest rates.

But to give a final answer to such a question, the financial costs cannot be viewed isolated. It is necessary to develop a Public Sector Comparator, for the analysis of the overall project costs. If this cost in the PPP-model results in a lower amount than the costs of a traditional model, the project will be realised through PPP. If the calculations show that the PPP-model is more expensive than the traditional one, the project will be performed directly through the public sector. In the case analysis of the City of Monheim it can be clearly seen, that the overall cost for 25 years of the traditional model is 100 mil euro, whereby the overall cost of the PPP-model for the same period is 87,5 mil euro. That makes a saving of 12,4 mil euro or $12,4 \%$, though the financing costs where higher for $5 \%$ in the PPP-model.

The PPP-projects are realised in several stages and consist of several public tasks, transferable to the private sector. When total project costs are taken in consideration, then the higher financial costs, which appear when private financing of public infrastructure is employed, may be compensated by the savings reached by the private partner in total project costs (i.e. in individual tasks of public ventures transferred to the private partner). This is the consequence of a major efficiency of the private sector in relationship to the public 
Livijo Sajko

Financial aspects of Public-Private Partnership

sector, but also a consequence of better private partner efficiency, when several public tasks are bundled and transferred as one public venture. This gives the private partner more freedom for efficient economic acting.

In such a way, a clear picture in terms of figures is obtained, which evidently shows how the employment of private capital will reflect not only to financial costs, but also to other ventures within the PPP-model, and what the financial and other costs will be, in case where the private capital is left aside. If the overall project costs in the PPP-model are lower than the ones reached by the public administration, the decision can be made to build public infrastructure by PPP-models and the employment of private capital in PPP-projects will be valid from the economy point of view.

Livijo Sajko has graduated at the Faculty of Tourism and Hotel management in Opatija and is a student on the master's study of Public Administration at the Faculty of Economics in Rijeka, University of Rijeka. He is a lecturer at the Faculty of Philosophy in Rijeka, teaching entrepreneurship, and a member of the Rijeka City Council for economic development and entrepreneurship. 


\section{Financial aspects of Public-Private Partnership}

\section{Bibliography}

- Gasteyer, T. (2003): Prozessleitfaden Public Private Partnership, Clifford Chance Pünder, Frankfurt am Main.

- Grad Rijeka, Proračun, http://www.rijeka.hr.

- Hrvatska Narodna Banka, Statistika, http://www.hnb.hr/statistika/hstatistika.htm

- Jacob, D. (2003): Erstellung eines Gerüsts für einen PSC bei 4 Pilotprojekten im Schulbereich, Technische Universität Bergakademie Freiberg, Fakultät für Wirtschaftswissenschaften, Freiberg.

- Jurčić, D., Veljković, D. (2001): Financiranje kapitalnih projekata lokalnog javnog sektora, Vitagraf, Rijeka.

- Merna, T., Njiru, C. (2002): Financing Infrastructure Projects, Thomas Telford, London.

- Ministarstvo financija Republike Hrvatske, Državni Proračun, http://www.mfin.hr.

- Otten, N. (2005): Kooperation zwischen öffentlichen und privatwirtschaftlichen Partnern, Kölner Arbeitspapiere zur internationalen Politik, 2005, Nr. 21.

- Public Private Finance, Europe Country Studies, http://www.publicprivatefinance.com.

- $\quad$ Public Private Partnership - Initiative NRW (2003): Der PPP-Eignungstest, Finanzministerium NRW.

- $\quad$ Public Private Partnership - Initiative NRW (2004): Finanzierungsleitfaden, Finanzministerium NRW.

- Public Private Partnership - Initiative NRW (2003): Organisationsmodelle, Finanzministerium NRW.

- Public Private Partnership - Initiative NRW (2003): Wirtschaftlichkeitsvergleich, Finanzministerium NRW.

- Republika Hrvatska - Državni Zavod za Statistiku, Statistički ljetopis 2006, http://www.dzs.hr.

- $\quad$ Sikirić, S. (2004): Ekonomska decentralizacija i lokalna samouprava - Upravljanje financijama i proračunom lokalne samouprave, Sveučilište Rijeka, Ekonomski Fakultet Rijeka, Rijeka

- Smith, A. (1999): Privatized Infrastructure: The Role of Government; Thomas Telford, London

- Stadt Monheim am Rhein, http://www.monheim.de/stadtprofil/schulen/ppp/.

- Walker, C., Smith, A. (1999): Privatized Infrastructure: The BOT Approach, Thomas Telford, London

- Zračna luka Zagreb, Zagreb Airport, Poslovne informacije, Promet, Statistika

- $\quad$ http://www.zagreb-airport.hr/hr/poslovne_4_4/index.aspx 
Livijo Sajko

Financial aspects of Public-Private Partnership

POVZETEK

\section{FINANČNI VIDIKI JAVNO-ZASEBNEGA PARTNERSTVA}

Temeljna značilnost javno-zasebnega partnerstva (JZP) je sodelovanje javnega in zasebnega partnerja pri zagotavljanju javnih storitev. Teorija o principalu in agentu ter teorija o lastninski pravici služita kot teoretični okvir, ki nam kaže, da je glavni cilj JZP zagotoviti, da zasebni partner ustvarja dobiček na tak način, da so hkrati izpolnjeni interesi javnega sektorja oz. t.i. skupno dobro. Oba partnerja bosta motivirana, da projekt JZP uspe, če bosta imela $v$ njem lastninsko pravico. Zato je kot splošen model za JZP priporočljiva ustanovitev skupnega podjetja.

Glavni kriterij pri prenosu javnih nalog $v$ zasebni sektor je načelo "ustvarjanja dodatne vrednosti". Zasebni sektor uporablja javne vire in prejema povračilo za svoje delo iz javnega sektorja in/ali $v$ obliki naročnine uporabnikov. Zato bi moral zasebni partner zagotoviti določene standarde (zmogljivost, učinkovitost, prihranki, kvaliteta) pri zagotavljanju javnih storitev. To je mogoče doseči z optimalno razporeditvijo poslovnih tveganj med javnim in zasebnim partnerjem. $V$ primeru da javni sektor prenese zgolj del javnih nalog (izgradi in upravljaj) na zasebnega partnerja, potem je to model »izgradi-upravljaj-prenesi « ali BOT. Če javni sektor prenese vse javne naloge (razvij, izgradi, financiraj, upravljaj) na zasebni sektor, potem je to model "razvij-izgradi-financiraj-upravljaj" ali DBFO.

JZP lahko potemtakem definiramo kot sodelovanje javnega in zasebnega sektorja ter kot kompleksno in dolgoročno pogodbeno sodelovanje pri zagotavljanju javnih storitev brez dokončnega prenosa lastništva na zasebnega partnerja. JZP se nahaja med tradicionalnim modelom zagotavljanja javnih storitev in privatizacijo, ki se pojavlja v različnih oblikah.

$\checkmark$ vseh evropskih državah, $v$ vseh sektorjih javne uprave se je število javnih zahtevkov povečalo. Na Hrvaškem se je med letoma 1996 in 2005 prevoz potnikov z železnico povečal za $36,9 \%$, medtem ko je prevoz tovora narasel za 29,6 \%. Prevoz potnikov v morskih pristaniščih na Hrvaškem se je povečal za $121 \%$, medtem kot je prevoz tovora narasel za $87,5 \%$. Potniški promet na letališčih se je povečal za $144 \%$, medtem kot je prevoz tovora po zraku narasel za $16,3 \%$. Cestni promet je doživel največje spremembe. Medtem ko je med letoma 1996 in 2005 število potnikov v cestnem prometu upadlo za $25 \%$, je med letoma 2001 in 2005 prevoz tovora v cestnem prometu narasel za $44 \%$. 
Okvir javne finančne analize uporabljamo za oceno fiskalnih pogojev $v$ javnih proračunih in za identificiranje finančnih sredstev, ki so na voljo za investicije, da bi zadostili predhodno ugotovljenim zahtevkom. V primeru mesta Reka so kapitalski zahtevki znašali 15,2 milijona kun v letu 2005 in 58,3 milijona kun $v$ letu $2004-s$ tendenco hitre rasti. Težavo so rešili $z$ novim zadolževanjem in z izdajo vrednostnih papirjev.

Analiza lokalnih uprav na Hrvaškem z enako metodo finančne analize je pokazala, da so kapitalski zahtevki hitro naraščali. Med letoma 2003 in 2006 se je ta vrsta zahtevkov povečala s 385 milijonov kun na 1,4 milijarde kun. Glavni instrument za zadostitev tem zahtevkom v navedenem obdobju je bilo določilo posojilnih pogodb. $V$ povprečju so bile lokalne uprave zadolžene za 525 milijonov kun na leto. Neto finančne transakcije (vrednostni papirji) so v letu 2004 dali 108 milijonov kun prihodkov.

$\checkmark$ državnem proračunu Hrvaške $v$ istem obdobju so se kapitalski zahtevki povečali s 5,7 milijarde kun $v$ letu 2002 na 10,3 milijarde kun $v$ letu 2004. $V$ naslednjih dveh letih je ta trend stagniral pri 8,7 milijarde kun $v$ letu 2005 in pri 9,7 milijarde kun $\vee$ letu 2006. $\vee$ povprečju so bilanco državne uprave bremenili za 3 milijarde kun, da bi zadostili navedenim zahtevam. Izdaja vrednostnih papirjev je dala prihodek $v$ višini 5,5 milijarde kun na leto.

$\checkmark$ pogojih, ko je nemogoče zagotoviti zadostne prilive za izgradnjo javne infrastrukture, se javni sektor za dodatne vire financiranja obrne na zasebni kapital in JZP. Razvoj trga JZP v Franciji in Nemčiji je to jasno pokazal. Leta 2005 so v Franciji realizirali 28 projektov JZP; leta 2006 je številka narasla na 62 projektov. Leta 2005 so v Nemčiji izpeljali 40 projektov JZP; leta 2006 je številka narasla na 106 projektov. Ker se uporaba projektov JZP povečuje, se kot eno glavnih vprašanj zastavlja vprašanje, ali je uporaba zasebnega kapitala $v$ projektih JZP ekonomsko upravičena?

Gibanje obrestnih mer na denarnem trgu na Hrvaškem je bilo pozitivno. Od leta 2000 naprej so bile obrestne mere ustaljene pod $5 \%$. Taki trendi, ki so podobni tistim $v$ drugih evropskih državah, kažejo na ugodne pogoje pri financiranju projektov javne infrastrukture neposredno iz javnega sektorja, ker vključitev zasebnega kapitala pogosto zahteva višje obrestne mere.

Da bi dali končni odgovor na zgornje vprašanje, bi morali razviti Primerjalnik za javni sektor (PSC), tako da bi bilo mogoče primerjati celotne stroške projekta. Če model JZP $\vee$ primerjavi $s$ tradicionalnim modelom 
Livijo Sajko

Financial aspects of Public-Private Partnership

javnega sektorja izkaže nižjo vsoto celotnih stroškov projekta, potem bo projekt izveden z modelom JZP, tudi če so stroški financiranja višji.

Ker je na Hrvaškem večina modelov JZP še na začetku, zaradi česar je bilo zbiranje podatkov do zdaj nemogoče, predstavljam analizo primera šolskega projekta JZP mesta Monheim (Nemčija, Zvezna dežela Severno Porenje-Vestfalija). Potem ko so razvili model JZP, so se odločili, da bodo finančni vidik projekta JZP testirali s PSC. Rezultati testa so bili, da bi celotni stroški po tradicionalnem modelu za 25 let znašali 100 milijonov evrov, medtem ko bi celotni stroški projekta JZP za isto obdobje znašali 87,5 milijona evrov. Torej bi prihranili 12,4 milijona evrov ali $12,4 \%$, pa čeprav bi bili po modelu JZP stroški financiranja višji za $5 \%$.

Torej, če so celotni stroški projekta $v$ okviru modela JZP nižji od stroškov $\mathrm{v}$ okviru tradicionalnega modela javnega sektorja, se je mogoče odločiti za izgradnjo javne infrastrukture z uporabo zasebnega kapitala, ker je to ekonomsko upravičeno. 